\title{
Metformin improves the sensitivity of ovarian cancer cells to chemotherapeutic agents
}

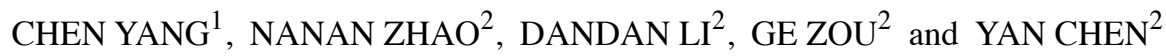 \\ ${ }^{1}$ School of Medicine, Tsinghua University, Beijing 100084; ${ }^{2}$ Department of Obstetrics and Gynecology, \\ North China University of Science and Technology Affiliated Hospital, Tangshan, Hebei 063000, P.R. China
}

Received October 18, 2018; Accepted June 11, 2019

DOI: $10.3892 / \mathrm{ol} .2019 .10564$

\begin{abstract}
Ovarian cancer is a common tumor of the reproductive system, and primarily responds to cytoreductive surgery and cisplatin (DDP)-based chemotherapy. However, chemoresistance results in high ovarian cancer mortality. Therefore, the aim of the present study was to investigate the effects of metformin on the apoptosis and autophagy of ovarian cancer drug-resistant SKOV3/DDP cells. To do so, MTT assay, flow cytometry, electron microscopy and western blotting were used in the present study. Metformin could inhibit the growth of SKOV3 and SKOV3/DDP cells in a concentrationand time-dependent manner $(\mathrm{P}<0.05)$. The half-inhibitory concentration $\left(\mathrm{IC}_{50}\right)$ values of DDP and methotrexate (MTX) were 14.35 and $4.21 \mu \mathrm{g} / \mathrm{ml}$ for SKOV3 cells, and 70.26 and $15.27 \mu \mathrm{g} / \mathrm{ml}$ for SKOV3/DDP cells, respectively. In addition, the resistance index of SKOV3/DDP for DDP and MTX was 4.89 and 3.62, respectively. After combining metformin with DDP and MTX, the $\mathrm{IC}_{50}$ values for SKOV3 cells were 11.20 and $2.80 \mu \mathrm{g} / \mathrm{ml}$, and 6.21 and $2.74 \mu \mathrm{g} / \mathrm{ml}$ for SKOV3/DDP cells, respectively. Metformin decreased the $\mathrm{IC}_{50}$ of DDP and MTX in drug-resistant cancer cells SKOV3/DDP by 11.31- and 6.18-fold. This indicated that cell proliferation was inhibited when treated with the combination of metformin and chemotherapeutic agents, compared with chemotherapeutic agents alone. In addition, autophagy was not observed in SKOV3 and SKOV3/DDP cells; however, it was observed in SKOV3/DDP cells following incubation with $10 \mathrm{mmol} / \mathrm{l}$ metformin for $48 \mathrm{~h}$. Furthermore, the expression levels of microtubule-associated protein 1 light chain 3-II protein in SKOV3/DDP cells were upregulated compared with in SKOV3 cells $(\mathrm{P}<0.05)$. These results demonstrated that metformin can sensitize drug-resistant ovarian cancer cells to
\end{abstract}

Correspondence to: Professor Yan Chen, Department of Obstetrics and Gynecology, North China University of Science and Technology Affiliated Hospital, 73 Jianshe Road, Tangshan, Hebei 063000, P.R. China

E-mail: yanchen0806@yahoo.com

Key words: metformin, ovarian cancer, resistant, apoptosis, autophagy chemotherapeutic agents, and that it may be associated with the induction of autophagy.

\section{Introduction}

Ovarian cancer has one of the highest rates of mortality in the USA, and is the leading cause of cancer-associated mortality in women (1). Diagnosis of ovarian cancer is a problem, as early stages have no noticeable signs or symptoms (2). The majority of patients are diagnosed at an advanced stage of the disease, which is mainly treated with cytoreductive surgery and platinum-based chemotherapy. However, 60-65\% of patients will subsequently relapse, and a low five-year survival rate is observed following the initial diagnosis (3). The high mortality rate for ovarian cancer is primarily caused by chemoresistance, which remains an important obstacle to successful chemotherapy (4). Therefore, it is necessary to find a novel therapeutic approach to improve the effects of ovarian cancer treatment.

Cell death mainly includes apoptosis, autophagy and necrosis. Disruption in the balance between cell proliferation and apoptosis leads to uncontrollable cell growth and tumorigenesis; therefore, apoptosis can inhibit tumor growth $(5,6)$. The majority of chemotherapy drugs kill cancer cells by inducing apoptosis (5). It has previously been reported that chemoresistance of tumor cells is not only associated with inhibiting apoptosis and reducing apoptotic susceptibility, but is also associated with autophagy $(7,8)$. Autophagy is a self-stabilizing mechanism in eukaryotic cells that allows the orderly degradation and recycling of cellular components (9). This self-degradation process not only serves a crucial role in cell protection but can also be involved in cell killing (10). Hence, autophagy and apoptosis can work individually, and can affect the sensitivity of tumor cells to chemotherapy in a reciprocal manner $(11,12)$. However, to the best of our knowledge, whether autophagy protects or kills cells remains unclear.

Metformin as an insulin sensitization agent was formally approved as a first-line treatment for diabetes by the American Diabetes Association and European Association for the Study of Diabetes (13). Previous studies have revealed that metformin can not only effectively reduce blood sugar levels and regulate lipid metabolism, endocrine function, hypercoagulability and hyperthrombocytopenia, but may 
also possess antitumor effects (13-15). It has been reported that metformin can inhibit breast, prostate, renal, pancreatic and colon cancer in animal and cell experiments (16-19). The antitumor effects of metformin are induced by the inhibition of tumor cell proliferation, promotion of apoptosis in tumor cells, activation of tumor sensitivity to chemotherapeutic agents and inhibition of tumor angiogenesis (19). However, research into the effects of metformin on ovarian cancer is currently limited.

The present study investigated the effects of metformin on cisplatin (DDP) and methotrexate (MTX)-induced apoptotic cell death in epithelial ovarian cancer parental SKOV3 and drug-resistant SKOV3/DDP cells. Metformin inhibited the growth of SKOV3/DDP cells and enhanced the sensitivity of SKOV3/DDP cells to chemotherapeutic agents.

\section{Materials and methods}

Chemical reagents. Metformin, MTT, DDP, MTX, ribonuclease A (RNase A), DAPI, fluorescein isothiocyanate isomer (FITC), propidium iodide (PI), dimethyl sulfoxide (DMSO), ethanol, formaldehyde, glutaraldehyde, epoxy resin, acetone and Nonidet P-40 were purchased from Sigma-Aldrich (Merck KGaA). RPMI 1640 medium, fetal bovine serum (FBS), penicillin and streptomycin were obtained from Thermo Fisher Scientific, Inc. Polyclonal antibodies against microtubule-associated protein 1 light chain 3 (LC3), goat anti-rabbit IgG conjugated to horseradish peroxidase (HRP) and anti- $\beta$-actin antibody were purchased from Santa Cruz Biotechnology, Inc. An Annexin V-FITC apoptosis detection kit was purchased from Xi'an Jiaoda Bao Sai Bio-technology Co., Ltd. A Pierce ${ }^{\mathrm{TM}}$ Bicinchoninic Acid (BCA) Protein Assay kit was supplied by Thermo Fisher Scientific, Inc. Total cell protein extraction kit was purchased from Shanghai BestBio Biotechnology Co., Ltd. All other chemicals and solvents were purchased from Sigma-Aldrich (Merck KGaA).

Cell culture. The ovarian cancer cell lines SKOV3 and SKOV3/DDP were provided by the Institute of Basic Medicine, Chinese Academy of Medical Sciences \& Peking Union Medical College. Both parental and drug-resistant cells were cultured in RPMI 1640 medium, supplemented with $10 \%$ FBS, $100 \mathrm{U} / \mathrm{ml}$ penicillin and $100 \mu \mathrm{g} / \mathrm{ml}$ streptomycin at $37^{\circ} \mathrm{C}$ with $5 \% \mathrm{CO}_{2}$.

MTT assay. An MTT assay was used to evaluate the resistance index (RI) of SKOV3 and SKOV3/DDP cells. Cells were

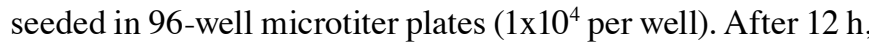
different concentrations of DDP $(12.5,25,50$ and $100 \mu \mathrm{g} / \mathrm{ml})$ or MTX $(2,4,8$ and $16 \mu \mathrm{g} / \mathrm{ml})$ were added to the cells for $72 \mathrm{~h}$ at $37^{\circ} \mathrm{C}$. Cells were washed with PBS and incubated with MTT $(50 \mu \mathrm{l} ; 0.5 \mathrm{mg} / \mathrm{ml})$. After $4 \mathrm{~h}$ incubation at $37^{\circ} \mathrm{C}$, the formazan precipitates were dissolved in DMSO (150 $\mu \mathrm{l} /$ well). The optical density (OD) was measured at a wavelength of $570 \mathrm{~nm}$ using a Benchmark microplate reader (Bio-Rad Laboratories, Inc.). The $\mathrm{OD}$ values were used to calculate the inhibition rates and half-inhibitory concentration $\left(\mathrm{IC}_{50}\right)$ of chemotherapeutic agents. The ratio of $\mathrm{IC}_{50}$ for drug-resistant and parental cells (RI), was calculated to evaluate the drug-resistance of
SKOV3/DDP cells. The MTT assay was performed in triplicate.

The MTT assay was also used to evaluate the effect of the tested compounds on the viability of SKOV3/DDP cells. After the cells were seeded in a 96-well microtiter plates for $12 \mathrm{~h}$, different concentrations of metformin $(2.5,5$ and $10 \mathrm{mmol} / \mathrm{l})$ were added. The cells were incubated for 24,48 and $72 \mathrm{~h}$ at $37^{\circ} \mathrm{C}$ prior to the addition of MTT. To determine the susceptibility to metformin as a chemotherapeutic agent, the cells were incubated with $10 \mathrm{mmol} / 1$ metformin for $12 \mathrm{~h}$ at $37^{\circ} \mathrm{C}$, and different concentrations of DDP $(12.5,25,50$ and $100 \mu \mathrm{g} / \mathrm{ml})$ or MTX $(2,4,8$ and $16 \mu \mathrm{g} / \mathrm{ml})$ were subsequently added to the wells. The cells and agents were co-cultured for another $48 \mathrm{~h}$ at $37^{\circ} \mathrm{C}$ prior to the MTT assay.

Detection of apoptosis by flow cytometry. Following incubation of SKOV3 and SKOV3/DDP cells with different concentrations of metformin for $48 \mathrm{~h}$, attached and floating cells were harvested and washed twice with PBS. The cells were fixed with $70 \%$ ethanol at $4^{\circ} \mathrm{C}$ overnight, and then incubated in RNase A $(100 \mu \mathrm{g} / \mathrm{ml}$ in PBS $)$ at $37^{\circ} \mathrm{C}$ for $30 \mathrm{~min}$. Detection of apoptotic cells was performed using an Annexin V-FITC apoptosis detection kit including recombinant human Annexin V labelled by FITC, according to the manufacturer's protocol. After incubation with RNase A, cells $\left(1 \times 10^{6}\right)$ were washed with cold PBS prior to incubation with FITC (10 $\mu \mathrm{l})$ and PI $(5 \mu \mathrm{l})$ for $15 \mathrm{~min}$ in the dark at $4^{\circ} \mathrm{C}$. The apoptotic rate was analyzed using flow cytometer (Beckman Coulter, Inc.) and quantified with CellQuest Pro V5.1 software (BD Biosciences).

Detection of apoptosis by DAPI staining. Following incubation of SKOV3 and SKOV3/DDP cells with indicated drugs (10 $\mathrm{mmol} / 1 \mathrm{DDP}$ or $10 \mathrm{mmol} / 1 \mathrm{metformin}$ or $10 \mathrm{mmol} / \mathrm{l}$ $\mathrm{DDP}+10 \mathrm{mmol} / 1 \mathrm{metformin}$ ) for $48 \mathrm{~h}$, attached and floating cells were both harvested and fixed at $4^{\circ} \mathrm{C}$ for $2 \mathrm{~h}$ with PBS solution containing $3.7 \%$ formaldehyde, $0.5 \%$ Nonidet P-40 and $0.1 \mathrm{mg} / \mathrm{l}$ DAPI. Apoptosis was assessed by fluorescence microscope (Olympus Corporation; magnification, x200) of condensed chromatin and micronucleation. Cells with a condensed and/or fragmented nucleus were considered as apoptotic cells. At least two independent experiments were carried out for each treatment condition and a minimum of 300 cells were counted by ImageJ V1.8.0 software (National Institutes of Health) in each experiment.

Detection of autophagy by electron microscopy. Metformin (10 mmol/l) was added to SKOV3 and SKOV3/DDP cells for $48 \mathrm{~h}$. Following centrifugation at room temperature for $10 \mathrm{~min}$ at $200 \mathrm{x} \mathrm{g}$ and cleaning, cells were fixed with $2.5 \%$ glutaraldehyde at $4^{\circ} \mathrm{C}$ overnight. Fixed cells were stained with $1 \%$ uranium acetate at room temperature for $10 \mathrm{~min}$, washed with double distilled water for $20 \mathrm{sec}$, subsequently stained with $0.2 \%$ lead citrate at room temperature for $10 \mathrm{~min}$ and washed with double distilled water for $20 \mathrm{sec}$. Then, the specimens were rinsed with PBS, dehydrated in a graded acetone series $(50,70$, 80,90 and 100\%) and embedded in an epoxy resin/acetone (1:1) mixture at room temperature for $1 \mathrm{~h}$. Ultra-thin sections (50-60 nm) were examined by the FEI TecnaiG2 F20 transmission electron microscope (TEM; magnification, $\mathrm{x} 15,000$; FEI Company). 
Table I. Inhibition rates of metformin with indicated concentrations and incubation times in SKOV3 and SKOV3/DDP cells.

\begin{tabular}{|c|c|c|c|c|c|}
\hline Concentration $(\mathrm{mmol} / \mathrm{l})$ & Time (h) & SKOV3 $(\% \pm \mathrm{SD})$ & SKOV3/DDP $(\% \pm S D)$ & t-statistic & P-value \\
\hline \multirow[t]{3}{*}{2.5} & 24 & $10.80 \pm 1.78$ & $13.14 \pm 2.94$ & 0.290 & 0.779 \\
\hline & 48 & $18.41 \pm 1.94$ & $16.84 \pm 1.90$ & -0.470 & 0.651 \\
\hline & 72 & $22.20 \pm 1.19$ & $24.89 \pm 2.22$ & 3.275 & 0.061 \\
\hline \multirow[t]{3}{*}{5} & 24 & $16.25 \pm 1.60$ & $18.82 \pm 1.92$ & 3.301 & 0.050 \\
\hline & 48 & $23.01 \pm 2.76$ & $22.46 \pm 2.56$ & -0.330 & 0.750 \\
\hline & 72 & $27.62 \pm 1.62$ & $31.84 \pm 2.25$ & 3.398 & 0.009 \\
\hline \multirow[t]{3}{*}{10} & 24 & $20.30 \pm 1.69$ & $27.97 \pm 1.82$ & 6.904 & $<0.001$ \\
\hline & 48 & $27.95 \pm 2.69$ & $34.35 \pm 2.39$ & 3.984 & 0.004 \\
\hline & 72 & $33.30 \pm 3.56$ & $38.04 \pm 2.90$ & 2.309 & 0.041 \\
\hline
\end{tabular}

$\mathrm{N}=3$ /group. DDP, cisplatin; $\mathrm{SD}$, standard deviation.

Western blot analysis for the detection of protein-associated apoptosis and autophagy. Total proteins were extracted from cells following the aforementioned treatments with the total cell protein extraction kit (cat. no. BB-3101; Shanghai BestBio Biotechnology Co., Ltd.) and proteins were quantified using a BCA Protein Assay kit (Thermo Fisher Scientific), according to the manufacturer's protocol. Equal amounts of proteins $(80 \mu \mathrm{g} /$ lane) were separated via SDS-PAGE $(12 \%$ gels), and transferred to nitrocellulose membranes (Bio-Rad Laboratories, Inc.). The membrane was probed with polyclonal antibodies against LC3 (cat. no. sc398822; 1:500) overnight at $4^{\circ} \mathrm{C}$, followed by incubation with HRP-conjugated secondary antibody (cat. no. sc2030; 1:3,000) at room temperature for $2 \mathrm{~h}$. Visualization was achieved using Super Signal enhanced chemiluminescence (Applygen Technologies, Inc.). The data were analyzed via densitometry using Quantity One V4.6.2 software (Bio-Rad Laboratories, Inc.). To determine equal lane loading, the membrane was stripped and re-probed with anti- $\beta$-actin antibody (cat. no. sc47778; 1:5,000).

Statistical analysis. Statistical analysis was performed using SPSS software (version 17.0; SPSS, Inc.) and SAS 9.4 (SAS Institute Inc.). All experiments were repeated as least in triplicate, and the values were presented as the mean \pm standard deviation. A two-way analysis of variance was applied to compare the main and interactive effects of variables, followed by Bonfferoni post hoc test. $\mathrm{P}<0.05$ was considered to indicate a statistically significant difference.

\section{Results}

Metformin reduces viability and induces apoptosis in ovarian cancer cells. Metformin could inhibit the growth of SKOV3 and SKOV3/DDP cells, whereas inhibition rates were increased in a drug concentration- and time-dependent manner (Table I), suggesting that both cells were sensitive to metformin. In particular, when the concentration of metformin was $10 \mathrm{mmol} / 1$, the inhibitory effect was increased in SKOV3/DDP cells compared with SKOV3 cells $(\mathrm{P}<0.05)$. For the detection of metformin-induced apoptosis, flow cytometric analysis was performed. As presented in Fig. 1, when 2.5, 5
Table II. Comparison by two way ANOVA of the effects of metformin concentration and cell type, alone and combined, on apoptotic rates.

\begin{tabular}{lrc}
\hline Factor & F-value & P-value \\
\hline Metformin concentration $^{\mathrm{a}}$ & 707.130 & 0.000 \\
Cell type $^{\mathrm{b}}$ & 11.070 & 0.004 \\
Metformin concentration $^{*}$ Cell type $^{\mathrm{c}}$ & 4.212 & 0.022 \\
\hline
\end{tabular}

${ }^{a}$ Main effect of metformin concentration on apoptotic rates; ${ }^{b}$ Main effect of cell type on apoptotic rates; 'Interaction effect between metformin concentration and cell type on apoptotic rates.

and $10 \mathrm{mmol} / \mathrm{l}$ metformin were incubated for $48 \mathrm{~h}$, the apoptotic rates of SKOV3/DDP cells were $11.45 \pm 2.78,33.28 \pm 1.30$ and $40.36 \pm 2.58 \%$, respectively, whereas the apoptotic rates of SKOV3 cells were $10.56 \pm 1.08,31.31 \pm 2.21$ and $35.60 \pm 3.24$, respectively (Tables II and III).

Effects of metformin on the cytotoxicity of SKOV3/DDP ovarian cancer cells. As presented in Table IV, the inhibition rates of DDP and MTX on SKOV3 and SKOV3/DDP cells were increased as the concentration of chemotherapeutic agents increased. The $\mathrm{IC}_{50}$ values of MTX and DDP were 4.21 and 14.35 for SKOV3 cells and 15.27 and $70.26 \mu \mathrm{g} / \mathrm{ml}$ for SKOV3/DDP cells, respectively (Table V). Therefore, the inhibition rates of DDP and MTX on SKOV3 cells were significantly increased compared with SKOV3/DDP cells $(\mathrm{P}<0.05)$. The SKOV3/DDP cell was resistant to DDP and MTX, and the RI values were 4.89 and 3.62, respectively.

To evaluate the effects of metformin on the cytotoxicity of chemotherapeutic agents, an MTT assay was performed. As indicated in Table $\mathrm{V}$, the $\mathrm{IC}_{50}$ values of metformin combined with MTX and DDP were 2.80 and $11.20 \mu \mathrm{g} / \mathrm{ml}$ for SKOV3 cells, and 2.47 and $6.21 \mu \mathrm{g} / \mathrm{ml}$ for SKOV3/DDP cells, respectively. Compared with the $\mathrm{IC}_{50}$ values for when chemotherapeutic agents were used alone, metformin decreased the $\mathrm{IC}_{50}$ of MTX and DDP in drug-resistant cancer cells, SKOV3/DDP, by 

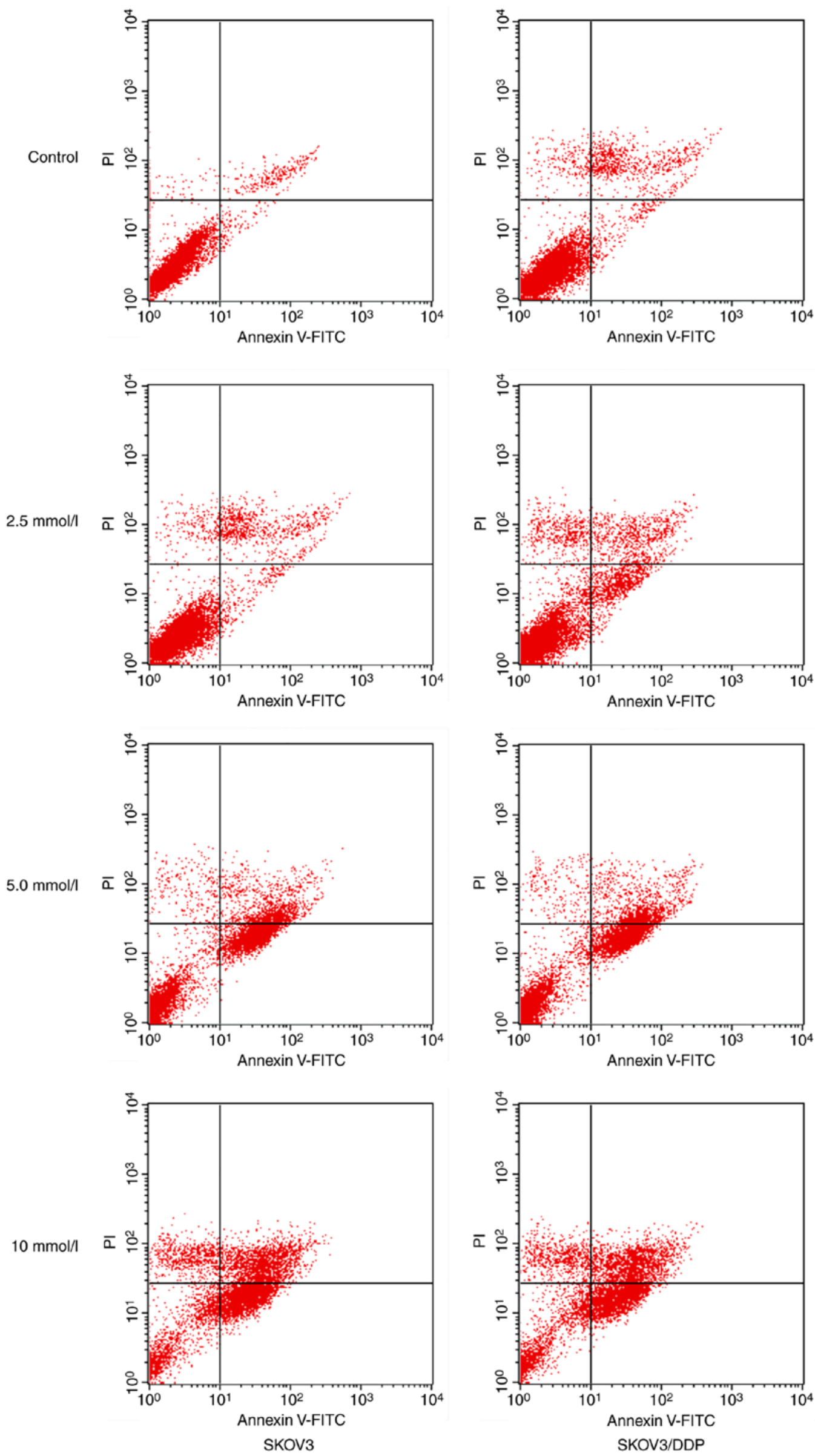

Figure 1. Metformin-induced apoptosis in SKOV3 and SKOV3/DDP cells. SKOV3 and SKOV3/DDP cells were incubated with different concentrations of metformin for $48 \mathrm{~h}$. FITC, fluorescein isothiocyanate isomer; PI, propidium iodide; DDP, cisplatin. 
Table III. Apoptotic rates detected using flow cytometry in SKOV3 and SKOV3/DDP cells following incubation with metformin for $48 \mathrm{~h}$.

\begin{tabular}{lcccr}
\hline Concentration $(\mathrm{mmol} / \mathrm{l})$ & SKOV3 $(\% \pm \mathrm{SD})$ & SKOV3/DDP $(\% \pm \mathrm{SD})$ & t-statistic & P-value \\
\hline 0 & $3.01 \pm 1.51$ & $3.13 \pm 1.32$ & 1.29 & 0.185 \\
2.5 & $10.56 \pm 1.08^{\mathrm{a}}$ & $11.45 \pm 2.78^{\mathrm{a}}$ & 2.05 & 0.172 \\
5 & $31.31 \pm 2.21^{\mathrm{a}}$ & $33.28 \pm 1.30^{\mathrm{a}}$ & 0.37 & 0.552 \\
10 & $35.60 \pm 1.24^{\mathrm{a}}$ & $40.36 \pm 2.58^{\mathrm{a}, \mathrm{b}}$ & 9.63 & 0.036 \\
\hline
\end{tabular}

${ }^{\mathrm{a}} \mathrm{P}<0.05$ vs. $0 \mathrm{mmol} / \mathrm{l} ;{ }^{\mathrm{b}} \mathrm{P}<0.05$ vs. SKOV3. $\mathrm{N}=3 /$ group. $\mathrm{DDP}$, cisplatin; $\mathrm{SD}$, standard deviation.

Table IV. Inhibition rates of DDP and MTX in SKOV3 and SKOV3/DDP cells.

\begin{tabular}{|c|c|c|c|c|c|c|c|c|}
\hline \multirow[b]{2}{*}{ Cell } & \multicolumn{4}{|c|}{ Concentration of DDP $(\mu \mathrm{g} / \mathrm{ml})$} & \multicolumn{4}{|c|}{ Concentration of MTX $(\mu \mathrm{g} / \mathrm{ml})$} \\
\hline & 12.5 & 25 & 50 & 100 & 2 & 4 & 8 & 16 \\
\hline SKOV3, \% \pm SD & $40.67 \pm 3.16$ & $59.81 \pm 2.66$ & $68.36 \pm 3.14$ & $75.12 \pm 1.22$ & $12.35 \pm 2.38$ & $40.17 \pm 1.18$ & $60.11 \pm 3.27$ & $80.12 \pm 2.49$ \\
\hline SKOV3/DDP, $\% \pm S D$ & $19.35 \pm 2.54^{\mathrm{a}}$ & $26.92 \pm 1.38^{\mathrm{a}}$ & $34.64 \pm 1.08^{\mathrm{a}}$ & $61.26 \pm 2.31^{\mathrm{a}}$ & $2.35 \pm 2.44^{\mathrm{a}}$ & $12.13 \pm 2.56^{\mathrm{a}}$ & $32.14 \pm 2.74^{\mathrm{a}}$ & $63.21 \pm 2.61^{\mathrm{a}}$ \\
\hline
\end{tabular}

${ }^{a} \mathrm{P}<0.05$ vs. SKOV3. $\mathrm{N}=3$ /group. DDP, cisplatin; MTX, methotrexate; SD, standard deviation.

Table V. Metformin sensitizes SKOV3 and SKOV3/DDP cells to chemotherapeutic agents.

\begin{tabular}{llccr}
\hline & & \multicolumn{2}{c}{$\mathrm{IC}_{50}(\mu \mathrm{g} / \mathrm{ml})$} & \\
\cline { 3 - 4 } Cell & Drug & Metformin $^{-}$ & Metformin $^{+}$ & Ratio $^{\mathrm{a}}$ \\
\hline SKOV3 & MTX & 4.21 & 2.80 & 1.50 \\
& DDP & 14.35 & 11.20 & 1.28 \\
SKOV3/DDP & MTX & 15.27 & 2.47 & 6.18 \\
& DDP & 70.26 & 6.21 & 11.31
\end{tabular}

${ }^{\mathrm{a}}$ Ratio $=\mathrm{IC}_{50}$ for Metformin $/ / \mathrm{IC}_{50}$ for Metformin ${ }^{+} . \mathrm{IC}_{50}$, half-inhibitory concentration; DDP, cisplatin; MTX, methotrexate.

6.18- and 11.31-fold, respectively. These results indicated that SKOV3/DDP cell viability was significantly inhibited when treated with the combination of metformin and chemotherapeutic agents compared with chemotherapeutic agents alone.

The effects of metformin on apoptosis were also evaluated using DAPI staining. Compared with chemotherapeutic agents alone, the combination of metformin and DDP significantly increased apoptotic rates. As indicated in Table VI, when DDP was replaced by the combination of metformin and DDP, the apoptotic rates for SKOV3/DDP significantly increased from 7.02 to $75.22 \%$; similarly, the apoptotic rates for SKOV3 cells increased from 24.50 to $74.12 \%$.

Metformin induces autophagy in drug-resistant ovarian cancer cells. Autophagy is characterized by the reformation of acidic vesicle and autophagic lysosomes, which
Table VI. Apoptotic rates detected by DAPI staining of SKOV3 and SKOV3/DDP cells following incubation with indicated drugs for $48 \mathrm{~h}$.

\begin{tabular}{lcc}
\hline Drug & $\begin{array}{c}\text { SKOV3 } \\
(\%)\end{array}$ & $\begin{array}{c}\text { SKOV3/ } \\
\text { DDP (\%) }\end{array}$ \\
\hline $10 \mathrm{mmol} / \mathrm{l} \mathrm{DDP}$ & 24.50 & 7.02 \\
$10 \mathrm{mmol} / \mathrm{l} \mathrm{metformin}$ & 35.60 & 41.38 \\
$10 \mathrm{mmol} / \mathrm{l} \mathrm{DDP}+10 \mathrm{mmol} / \mathrm{lmetformin}$ & 74.12 & 75.22 \\
\hline DDP, cisplatin. & & \\
\hline
\end{tabular}

are wrapped by a double membrane in the cytoplasm. For SKOV3 (Fig. 2A) and SKOV3/DDP (Fig. 2B) cells, no autophagosomes were observed using transmission electron microscopy. Following incubation with $10 \mathrm{mmol} / \mathrm{l}$ of metformin for $48 \mathrm{~h}$, there was no marked change in SKOV3 cells (Fig. 2C); however, autophagosomes were observed in SKOV3/DDP cells (Fig. 2D).

Metformin upregulates the expression of LC3-II in ovarian cancer cells. LC3 possesses two forms, including an $18-\mathrm{kDa}$ cytosolic protein (LC3-I) and a processed $16-\mathrm{kDa}$ form (LC3-II). The expression levels of LC3-II and the ratio of LC3-II/LC3-I represent autophagic activity (11). Therefore, LC3-I and LC3-II were detected in SKOV3 and SKOV3/DDP cells incubated with different concentrations of metformin for $48 \mathrm{~h}$ using western blot analysis. As indicated in Fig. 3, the expression levels of LC3-II in SKOV3/DDP cells were higher than those in SKOV3 cells, 

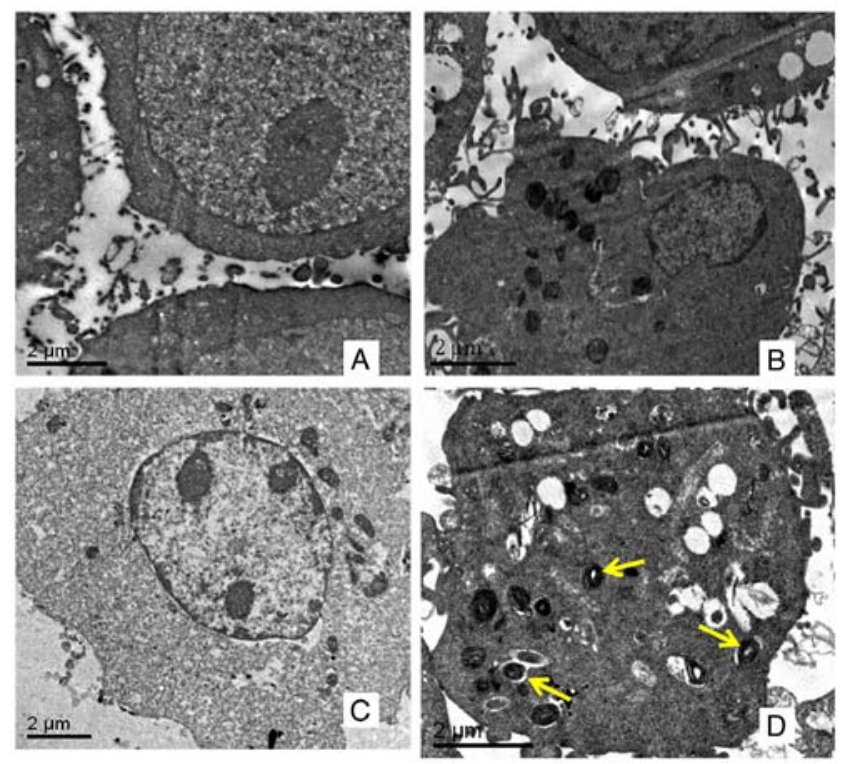

Figure 2. Autophagosomes observed using transmission electron microscopy. (A) SKOV3 and (B) SKOV3/DDP cells incubated without metformin for 48 h. (C) SKOV3 and (D) SKOV3/DDP cells incubated with metformin for $48 \mathrm{~h}$. Yellow arrows indicate autophagosomes. DDP, cisplatin.

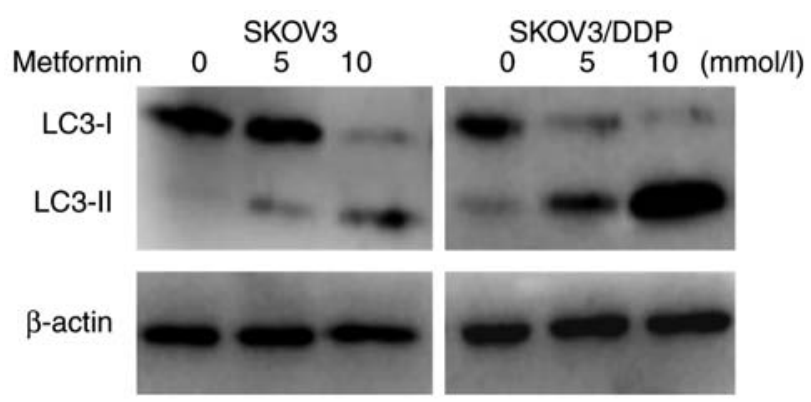

Figure 3. Expression levels of LC3-I and LC3-II in SKOV3 and SKOV3/DDP cells incubated with the indicated concentration of metformin for $48 \mathrm{~h} \mathrm{~s}$ as determined via western blot analysis. DDP, cisplatin; LC3, microtubule-associated protein 1 light chain 3; LC3-I, $18 \mathrm{kDa}$ cytosolic protein form of LC3; LC3-II, processed $16 \mathrm{kDa}$ form of LC3.

indicating that the autophagic activity of drug-resistant cells was increased compared with that of the parental cells. Metformin may induce autophagy in ovarian cancer cells. Following incubation with $10 \mathrm{mmol} / 1$ of metformin for $48 \mathrm{~h}$, the expression levels of LC3-II protein were significantly increased in SKOV3 and SKOV3/DDP cells, and the expression levels in SKOV3/DDP cells were higher compared with in SKOV3 cells (Fig. 4). These results demonstrated that metformin could promoted the autophagy of ovarian cancer cells, and served a crucial role in promoting autophagy in drug-resistant ovarian cancer cells.

\section{Discussion}

Ovarian cancer had the highest mortality rate among gynecologic malignant tumors in the USA in 2008 (20). At present, the leading therapeutic method for ovarian cancer is operative treatment combined with platinum-based chemotherapy; however, chemoresistance severely influences the

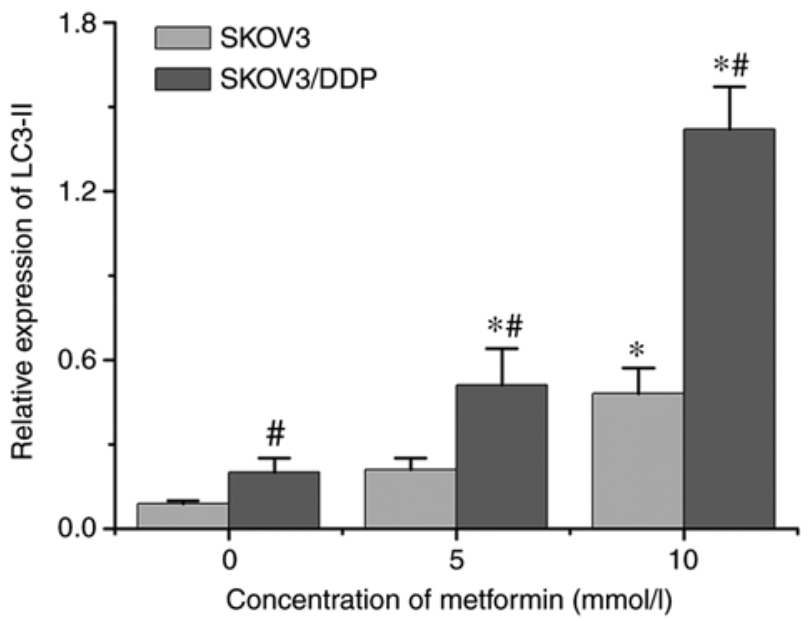

Figure 4. Relative expression levels of LC3-II protein in SKOV3 and SKOV3/DDP cells following incubation with the indicated metformin concentrations for $48 \mathrm{~h}$ (mean \pm standard deviation; $\mathrm{n}=3$ ). ${ }^{*} \mathrm{P}<0.05$ vs. $0 \mathrm{mmol} / 1$ metformin in the same cell type; ${ }^{\#} \mathrm{P}<0.05$ vs. SKOV 3 at the same concentration. LC3-II, processed $16 \mathrm{kDa}$ form of LC3; DDP, cisplatin; LC3, microtubule-associated protein 1 light chain 3 .

prognosis of the patient, and results in high mortality rates. Therefore, overcoming chemoresistance has become the key to treating ovarian cancer (4). Metformin is a member of biguanides group of drugs, and is a first-line drug for the treatment of type 2 diabetes (14). Metformin not only reduces blood sugar levels, but also possesses other pharmacological effects, including cardiovascular protective effects (21) and delaying Alzheimer's disease (22). Those patients with type 2 diabetes who received metformin had a decreased rate of cancer-associated mortality compared with those receiving sulfonylureas (3.5 vs. 4.9\%) (23). Metformin has been reported to enhance the antiproliferative effects of paclitaxel and cisplatin in breast cancer, lung cancer and other cells (24-27).

In the present study, metformin not only suppressed the growth of ovarian cancer parental SKOV3 cells and drug-resistant SKOV3/DDP cells, but it also sensitized drug-resistant SKOV3/DDP cells to chemotherapeutic agents. The inhibition rates of metformin increased in SKOV3 and SKOV3/DDP cells following drug treatment with increasing concentration and incubation time. In particular, when the concentration of metformin was $10 \mathrm{mmol} / 1$, significantly increased inhibition was observed in SKOV3/DDP cells compared with in SKOV3 cells. In addition, the apoptotic rates of the two cell types incubated with metformin for $48 \mathrm{~h}$ increased with increasing drug concentration. These results indicated that the two cell types were sensitive to metformin.

Metformin-induced chemosensitivity of ovarian cancer cells was examined via MTT assays and DAPI staining. Cell viability was markedly inhibited in both types of cells when treated with a combination of metformin and a chemotherapeutic agent (DDP or MTX) compared with those treated with chemotherapeutic agents alone. The $\mathrm{IC}_{50}$ values for the combination of metformin with DDT (or MTX) were reduced by 11.31- (or 6.18-) fold in SKOV3/DDP cells compared with DDT (or MTX) alone, but only 1.28- (or 1.50-) fold in SKOV3 cells. Similarly, following incubation with DDP 
alone for $48 \mathrm{~h}$, the apoptotic rates were 24.50 and $7.02 \%$ for SKOV3 and SKOV3/DDP cells, respectively, and the former were notably higher compared with the latter. With the combination of metformin and DDP, instead of DDP only, the apoptotic rates for SKOV3 and SKOV3/DDP cells were not significantly different; 74.12 and $75.22 \%$, respectively. These results demonstrated that metformin can enhance the cytotoxicity of chemotherapeutic agents on drug-resistant cancer cells.

Autophagy, as a type of cell death, degrades cellular components, and damaged organelles and macromolecular material are wrapped by cytomembrane to form a complete autophagosome; then, the autophagosome is combined with a lysosome and digested to complete the autophagy process $(9,10)$. Autophagy is considered a double-edged sword in the process of tumor development (10). The effects that autophagy has on tumor cells are complicated and controversial. Autophagy has been demonstrated to suppress carcinogenesis via the elimination of oncogenic molecules and damaged organelles (9). However, once an invasive cancer is established, autophagy promotes tumor growth via the intracellular recycling of degraded metabolites, which further stimulates the metabolism of cancer cells (28). In addition, autophagy is enhanced by chemotherapy and radiation therapy, and functions as an adaptive response that mediates resistance to these treatments (29). In particular, autophagy is associated with the occurrence and development of ovarian cancer, and also with DDP-resistance in ovarian cancer cells (30). In the present study, autophagy was significantly increased in SKOV3/DDP cells following incubation with metformin for $48 \mathrm{~h}$, resulting in cell death. The aforementioned, however, was not observed in SKOV3 cells. LC3-II is a marker of autophagosome formation. Incubation with metformin induced a significant increase in the expression levels of LC3-II, and the expression levels of LC3-II in drug-resistant cells were upregulated compared with in parental cells. Metformin enhanced the autophagy activity of ovarian cancer cells, and the effect was more prominent in SKOV3/DDP cells compared with that in SKOV3. The apoptotic rates of drug-resistant cells, with the incubation of combined metformin and DDP, were roughly equivalent to the apoptotic rates of the parental cells. These results indicated that metformin may sensitize drug-resistant SKOV3/DDP cells to chemotherapeutic agents through the induction of autophagy.

In conclusion, metformin not only induced apoptosis of ovarian cancer parental SKOV3 and drug-resistant SKOV3/DDP cells, but also enhanced autophagic activity in SKOV3/DDP cells. Therefore, the fact that metformin can sensitize drug-resistant ovarian cancer cells to chemotherapeutic agents may indicate an association with inducing autophagy. Although the specific underlying molecular mechanism remains unclear in the present study, metformin is a potential antitumor drug, particularly for the treatment of drug-resistant ovarian cancer. The results of the present study will be verified in future studies that include additional ovarian cancer cell lines and animal models.

\section{Acknowledgements}

Not applicable.

\section{Funding}

This study was supported by the Provincial Outstanding Clinical Medical Talents Project funded by HeBei Government (grant. no. 2016-361036).

\section{Availability of data and materials}

The datasets used and/or analyzed during the present study are available from the corresponding author on reasonable request.

\section{Authors' contributions}

CY and NZ performed the experiments. CY and YC drafted the manuscript. CY, DL and GZ analyzed the data. YC designed the study. All authors read and approved the final manuscript.

\section{Ethics approval and consent to participate}

Not applicable.

\section{Patient consent for publication}

Not applicable.

\section{Competing interests}

The authors declare that they have no competing interests.

\section{References}

1. Matei DE and Nephew KP: Epigenetic therapies for chemoresensitization of epithelial ovarian cancer. Gynecol Oncol 116: 195-201, 2010.

2. Gilbert L, Basso O, Sampalis J, Karp I, Martins C, Feng J, Piedimonte S, Quintal L, Ramanakumar AV, Takefman J, et al: Assessment of symptomatic women for early diagnosis of ovarian cancer: Results from the prospective DOvE pilot project. Lancet Oncol 13: 285-291, 2012.

3. Raja FA, Counsell N, Colombo N, Pfisterer J, du Bois A, Parmar MK, Vergote IB, Gonzalez-Martin A, Alberts DS, Plante M, et al: Platinum versus platinum-combination chemotherapy in platinum-sensitive recurrent ovarian cancer: A meta-analysis using individual patient data. Ann Oncol 24: 3028-3034, 2013.

4. Vecchione A,BellettiB,Lovat F, Volinia S, Chiappetta G, Giglio S, Sonego M, Cirombella R, Onesti EC, Pellegrini P, et al: A microRNA signature defines chemoresistance in ovarian cancer through modulation of angiogenesis. Proc Natl Acad Sci 110: 9845-9850, 2013.

5. Galluzzi L, Morselli E, Kepp O, Vitale I, Rigoni A, Vacchelli E, Michaud M,ZischkaH,Castedo Mand Kroemer G: Mitochondrial gateways to cancer. Mol Aspects Med 31: 1-20, 2010.

6. Hanahan D and Weinberg RA: The hallmarks of cancer. Cell 100: 57-70, 2000.

7. Schoenlein PV, Periyasamy-Thandavan S, Samaddar JS, Jackson WH and Barrett JT: Autophagy facilitates the progression of Eralpha-positive breast cancer cells to antiestrogen resistance. Autophagy 5: 400-403, 2009.

8. Ning L, Guo-Chun Z, Sheng-Li A, Xue-Rui L, Kun W, Jian Z, Chong-Yang R, Ling-Zhu W and Hai-Tong L: Inhibition of autophagy induced by PTEN loss promotes intrinsic breast cancer resistance to trastuzumab therapy. Tumor Biol 37: 5445-5454, 2016.

9. Mizushima N and Komatsu M: Autophagy: Renovation of cells and tissues. Cell 147: 728-741, 2011.

10. Macintosh RL and Ryan KM: Autophagy in tumour cell death. Semin Cancer Biol 23: 344-351, 2013.

11. Glick D, Barth S and Macleod KF: Autophagy: Cellular and molecular mechanisms. J Pathol 221: 3-12, 2010. 
12. Liang B, Kong D, Liu Y, Liang N, He M, Ma S and Liu X: Autophagy inhibition plays the synergetic killing roles with radiation in the multi-drug resistant SKVCR ovarian cancer cells. Radiat Oncol 7: 213, 2012.

13. Libby G, Donnelly LA, Donnan PT, Alessi DR, Morris AD and Evans JM: New users of metformin are at low risk of incident cancer: A cohort study among people with type 2 diabetes. Diabetes Care 32: 1620-1625, 2009.

14. Chan DK and Miskimins WK: Metformin and phenethyl isothiocyanate combined treatment in vitro is cytotoxic to ovarian cancer cultures. J Ovarian Res 5: 19, 2012.

15. Wang P, Kang D, Cao W, Wang Y and Liu Z: Diabetes mellitus and risk of hepatocellular carcinoma: A systematic review and meta-analysis. Diabetes Metab Res Rev 28: 109-122, 2011.

16. Bonanni B, Puntoni M, Cazzaniga M, Pruneri G, Serrano D, Guerrieri-Gonzaga A, Gennari A, Trabacca MS, Galimberti V and Veronesi P: Dual effects of metformin on breast cancer proliferation in a randomized trial. J Clin Oncol 30: 2593-2600, 2012.

17. Yu Z, Zhao G, Xie G, Zhao L, Chen Y, Yu H, Zhang Z, Li C and $\mathrm{Li}$ Y: Metformin and temozolomide act synergistically to inhibit growth of glioma cells and glioma stem cells in vitro and in vivo. Oncotarget 6: 32930-32943, 2015.

18. Sliwinska A, Rogalska A, Marczak A, Kasznicki J and Drzewoski J: Metformin, but not sitagliptin, enhances WP 631-induced apoptotic HepG2 cell death. Toxicol In Vitro 29 1116-1123, 2015.

19. Jara JA and López-Muñoz R: Metformin and cancer: Between the bioenergetic disturbances and the antifolate activity. Pharmacol Res 101: 102-108, 2015.

20. Jemal A, Siegel R, Ward E, Hao Y, Xu J, Murray T and Thun MJ: Cancer statistics, 2008. CA Cancer J Clin 58: 71-96, 2008.

21. Xiao H, Ma X, Feng W, Fu Y, Lu Z, Xu M, Shen Q, Zhu Y and Zhang Y: Metformin attenuates cardiac fibrosis by inhibiting the TGFbeta1-Smad3 signalling pathway. Cardiovasc Res 87: $504-513,2010$

22. Huang YC, Hsu CC, Lin WC, Yin TK, Huang CW, Wang PW, Chang HH and Chiu NT: Effects of metformin on the cerebral metabolic changes in type 2 diabetic patients. Scientific World Journal 2014: 694326, 2014.
23. Bowker SL, Majumdar SR, Veugelers P and Johnson JA: Increased cancer-related mortality for patients with type 2 diabetes who use sulfonylureas or insulin. Diabetes Care 29: 254-258, 2006.

24. Algire C, Amrein L, Zakikhani M, Panasci L and Pollak M: Metformin blocks the stimulative effect of a high-energy diet on colon carcinoma growth in vivo and is associated with reduced expression of fatty acid synthase. Endocr Relat Cancer 17: 351-360, 2010.

25. Jiralerspong S, Palla SL, Giordano SH, Meric-Bernstam F, Liedtke C, Barnett CM, Hsu L, Hung MC, Hortobagyi GN and Gonzalez-Angulo AM: Metformin and pathologic complete responses to neoadjuvant chemotherapy in diabetic patients with breast cancer. J Clin Oncol 27: 3297-3302, 2009.

26. Hadad SM, Coates P, Jordan LB, Dowling RJ, Chang MC, Done SJ, Purdie CA, Goodwin PJ, Stambolic V, Moulder-Thompson S and Thompson AM: Evidence for biological effects of metformin in operable breast cancer: Biomarker analysis in a pre-operative window of opportunity randomized trial. Breast Cancer Res Treat 150: 149-155, 2015.

27. Yerrabothala S, Shaaban H, Capo G, Maroules M and Debari VA: The impact of diabetes mellitus on breast cancer outcomes: A single center retrospective study. Pathol Oncol Res 20: 209-214, 2014.

28. White E: Deconvoluting the context-dependent role for autophagy in cancer. Nat Rev Cancer 12: 401-410, 2012

29. Hu YL, Jahangiri A, Delay M and Aghi MK: Tumor cell autophagy as an adaptive response mediating resistance to treatments such as antiangiogenic therapy. Cancer Res 72: 4294-4299, 2012.

30. Wang $\mathbf{J}$ and Wu GS: Role of autophagy in cisplatin resistance in ovarian cancer cells. J Biol Chem 289: 17163-17173, 2014. International (CC BY-NC-ND 4.0) License. 